\section{MASTER}

DOE/NASA CONTRACTOR REPORT
De. 2797

DOE/NASA CR-161230

\title{
THERMAL PERFORMANCE EVALUATION OF THE SEMCO (LIQUID) SOLAR COLLECTOR
}

Prepared by

Florida Solar Energy Center

300 State Road 401

Cape Canaveral, Florida 32920

Under Contract NAS8-32248 with

National Aeronautics and Space Administration

George C. Marshall Space Flight Center, Alabama 35812

For the U. S. Department of Energy

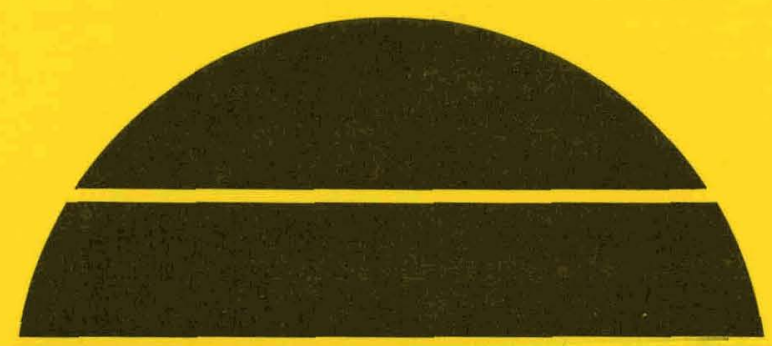

\section{U.S. Department of Energy}




\section{DISCLAIMER}

This report was prepared as an account of work sponsored by an agency of the United States Government. Neither the United States Government nor any agency Thereof, nor any of their employees, makes any warranty, express or implied, or assumes any legal liability or responsibility for the accuracy, completeness, or usefulness of any information, apparatus, product, or process disclosed, or represents that its use would not infringe privately owned rights. Reference herein to any specific commercial product, process, or service by trade name, trademark, manufacturer, or otherwise does not necessarily constitute or imply its endorsement, recommendation, or favoring by the United States Government or any agency thereof. The views and opinions of authors expressed herein do not necessarily state or reflect those of the United States Government or any agency thereof. 


\section{DISCLAIMER}

Portions of this document may be illegible in electronic image products. Images are produced from the best available original document. 


\section{NOTICE}

This report was prepared to document work sponsored by the United States Government. Nelther the UnIted States nor Its agents the United States Departmant of Energy, the United States National Aeronaut1cs and Space Adminlatration, nor any federsl employees, nor any of thef: contractors, sutcurtractors or their employees, make any varranty, express or inflite, or assume any legal liabllity or rasponsibllity for the sccuracy, completeness, or usefulness of any information, apparatus, product or process disclosed, or represent that its use would not infringe privately owned rights. 
TECHNICAL REPORT ST ANDARD TITLE PAGE'

\begin{tabular}{|c|c|}
\hline $\begin{array}{l}\text { 1. REPORT NO. } \\
\text { DOE/ NASA CR-161230 }\end{array}$ & 3. RECIPIENT'S CATALOG NO. \\
\hline \multirow{2}{*}{$\begin{array}{l}\text { 4. TITLE AND SUBTITLE } \\
\text { Thermal Performance Evaluation of the Semco (Liquid) Solar } \\
\text { Collector }\end{array}$} & $\begin{array}{l}\text { 5. REPORT DATE } \\
\text { May } 1979\end{array}$ \\
\hline & 6. PERFORMING ORGANIZATION CCIDE \\
\hline 7. AUTHOR(S) & 8. PERFORMING ORGANIZATION REPORT \# \\
\hline \multirow{3}{*}{$\begin{array}{l}\text { 9. PERFORMING ORGANIZATION NAME ANO ADORESS } \\
\text { Florida Solar Energy Center } \\
\text { 300 State Road } 401 \\
\text { Cape Canaveral, Florida } 32920\end{array}$} & 10. WORK UNIT. NO. \\
\hline & $\begin{array}{l}\text { 11. CONTRACT OR GRANT NO. } \\
\text { NAS } 8-32248\end{array}$ \\
\hline & 13.. TYPE OF REPOR $T$ \& PERIOD COVERED \\
\hline \multirow{2}{*}{$\begin{array}{l}\text { 12. SPONSORING AGENCY NAME AND ADDRESS } \\
\text { National Aeronautics and Space Administration } \\
\text { Washington, D. C. }\end{array}$} & Contractor Report \\
\hline & 14. SPONSORING AGENCY CODE \\
\hline
\end{tabular}

This work was done under the technical management of $\mathrm{Mr}$. Ralph Cole, George C. Marshall Space Flight Center, Alabama.

16. ABSTRACT

This report contains the procedures used and the results obtained during the evaluation test program on the SEMCO Corporation, Model FP 40-7DG (liquid) Solar Collector. The flat plate collector uses water as the working fluid. The absorber plate is copper tube soldered to copper fin coated with flat black paint. The glazing consists of two plates of Lo-Iron glass; the insulation is polyurethane foam. The collector weight is.242.5 pounds with overall external dimensions of approximately 48 . $8^{\prime \prime} \times 120.8^{\prime \prime} \mathrm{x}$ 4. $1^{\prime \prime}$.

The test program was conducted to obtain thermal performance data before and after 34 days of weather exposure test. These tests were conducted using Florida Solar Energy Center Test Facilities.

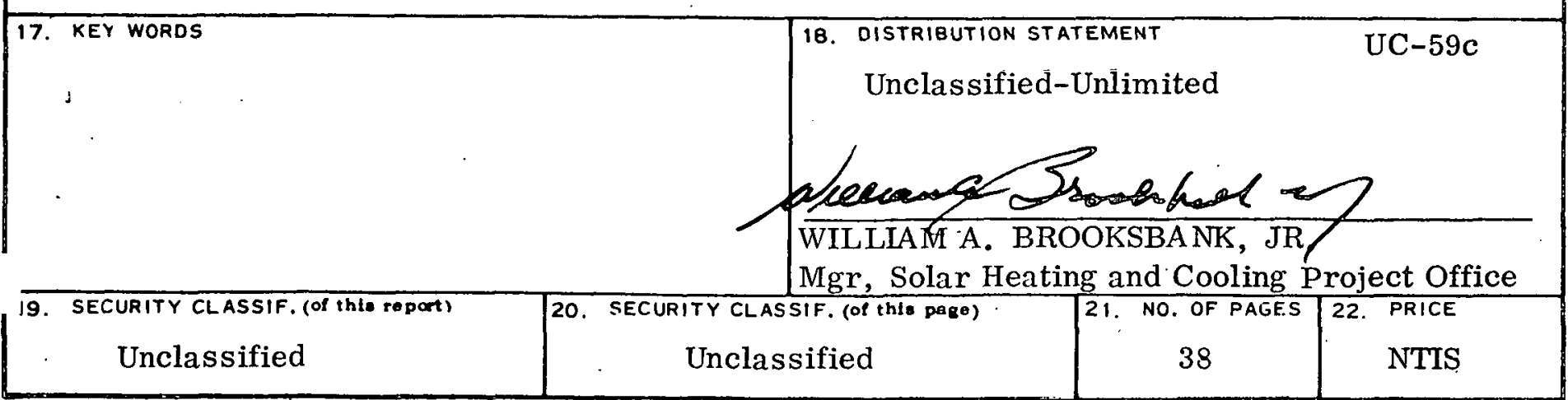


THIS PAGE

\section{WAS INTENTIONALLY LEFT BLANK}


1. Collector Description 2

1.1 Collector Identification 2

1.2 Collector Construction 2

2. Results 5

2.1 Introduction 5

2.2 Explanation of Results 5

Efficiency Curve 6

Incident Angle Modifier $\quad 8$

Data Tabulation 9

2.3 Computer Printout Key 11

2.4 Results of Static Tests $\cdot 12$

2.5 Explanation of Efficiency Curve 13

2.6 Performance Test Results, English Units 15

Appendix A

Test Facilities and Performance Test Procedures 20

Appendix B

Test Methods, Performance Ratings and Standards 


\section{SUMMARY INFORMATION SHEET}

FLORIDA SOLAR ENERGY CENTER

300 STATE ROAD 401, CAPE CANAVERAL, FLÓRIDA 32920, (305) 783.0300

FSEC \#78014

MANUFACTURER

SEIACO Corporation

$5201 \mathrm{NE}$ 14th Avenue

Collector Model

Fort Lauderdale, Florida 33334

FP-40-7-DG

This solar collector was tested by the Florida Solar Energy Center (FSEC) in accordance with prescribed methods and was found to meet the minimum standards established by FSEC. The purpose of the tests is to verify initial performance conditions and quality of construction only. The resulting certification is not a guarantee of long term performance or durability.

\section{DESCRIPTION}

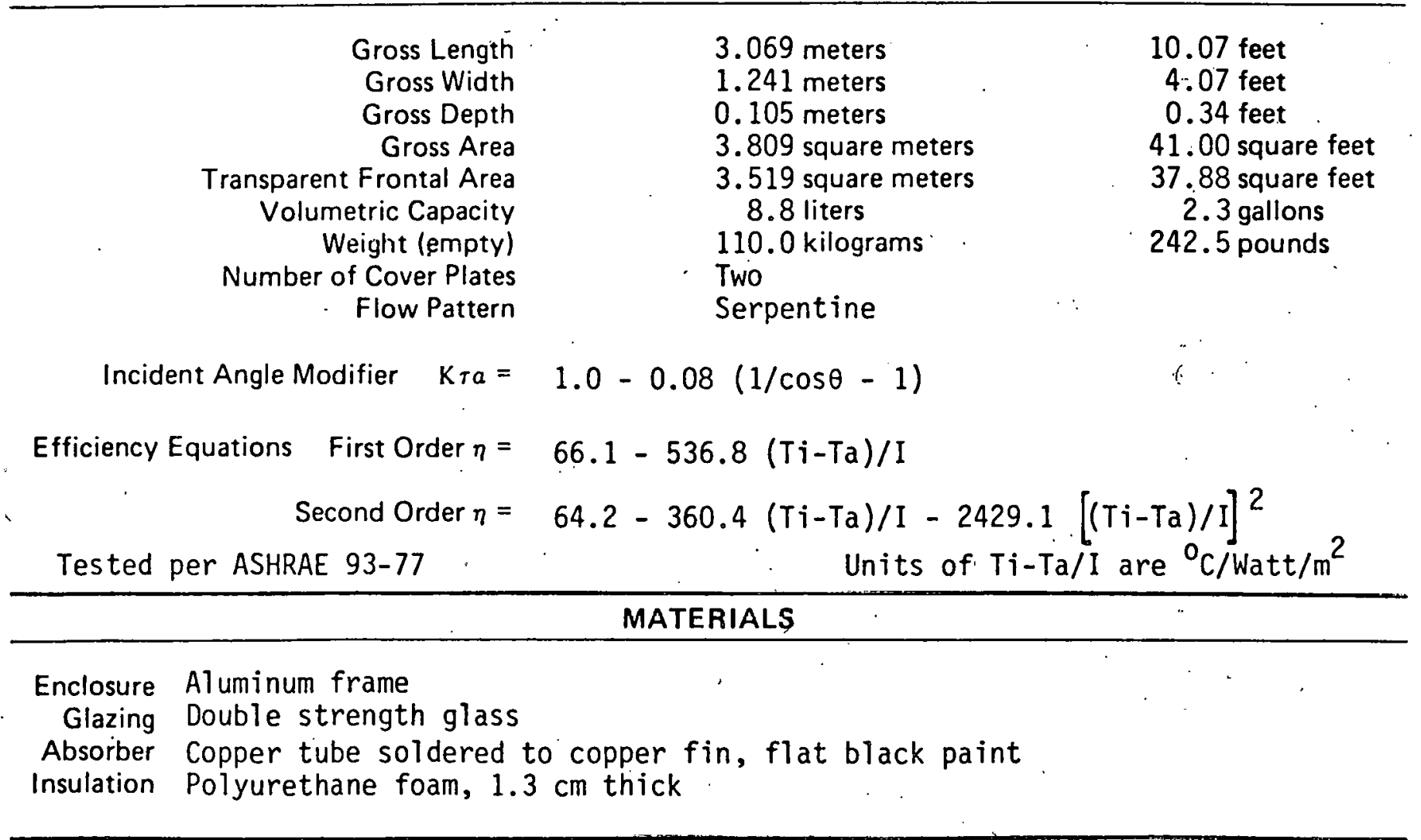

\section{RATING}

The collector has been rated for energy output on measured performance and an assumed standard day. Total solar energy available for the standard day is 5045 watt-hour $/ \mathrm{m}^{2}\left(1600 \mathrm{BTU} / \mathrm{ft}^{2}\right)$ distributed over a 10 hour period.

Output energy ratings for this collector based on the second-order efficiency curve are:

\section{Collector Temperature}

Low Temperature, $35^{\circ} \mathrm{C}\left(95^{\circ} \mathrm{F}\right)$

Intermediate Temperature, $50^{\circ} \mathrm{C}\left(122^{\circ} \mathrm{F}\right)$

High Temperature, $100^{\circ} \mathrm{C}\left(212^{\circ} \mathrm{F}\right)$

\section{Energy Output}

$\begin{array}{rlr}41,100 & \text { Kilojoules/day } & 39,000 \mathrm{BTU} / \text { day } \\ 32,000 & \text { Kilojoules/day } & 30,400 \mathrm{BTU} / \mathrm{day} \\ 6,700 & \text { Kilojoules/day } & 6,300 \mathrm{BTU} / \mathrm{day}\end{array}$


1. COLLECTOR DESCRIPTION

\subsection{Collector Identification}

Manufacturer and Address:

SEMCO Corporation

5201 NE 14th Avenue

Fort Lauderdale, Florida 33334

Collector Model Number:

$F P-40-7-D G$

\subsection{Collector Construction}

Overall Dimensions:

$\begin{array}{ll}\text { Length: } & 3.069 \mathrm{~m} \\ \text { Width: } & 1.241 \mathrm{~m} \\ \text { Depth: } & 0.105 \mathrm{~m}\end{array}$

Overall Front Area: (length $\mathrm{x}$ width) - $3.809 \mathrm{~m}^{2}$

Height of outlet above inlet when collector tilt is $90^{\circ}: 1.03 \mathrm{~m}$ Glazing:

Material: Double strength glass

Thickness: $0.32 \mathrm{~cm}(0.125$ inch $)$

Transmittance ${ }^{\star}: \quad 79.4 \%$

No. of Cover Plates: Two

Transparent Frontal Dimensions:

Length: $2.956 \mathrm{~m}$

Width: $1.191 \mathrm{~m}$

Area: $\quad 3.519 \mathrm{~m}^{2}$

Absorber:

Materfal: Copper tube and copper fin

Length: $2.940 \mathrm{~m}$

Width: $\quad 1.230 \mathrm{~m}$

Area: $\quad 3.616 \mathrm{~m}^{2}$

Ausurber Coating: Flat black paint

Absorptivity*: $90 \%$

Emissivity*: $90 \%$ 
Interglazing Space: $1.3 \mathrm{~cm}$

Air Spacing Glazing to Absorber: Approx. $0.06 \mathrm{~m}$

Insulation:

Type: Polyurethane foam

Dimensions: $1.3 \mathrm{~cm}$

K-Factor*: 0.024 Watts $/ \mathrm{m}^{0} \mathrm{C} \quad\left(0.17 \mathrm{Btu} / \mathrm{hr}-\mathrm{ft}{ }^{2}-{ }^{0} \mathrm{~F} / \mathrm{in}\right)$

Heat Transfer Fluid:

Material: Water

Density: $977.81 \mathrm{~kg} / \mathrm{m}^{3}$ at $70^{\circ} \mathrm{C}$

Specific Heat: $4189.6 \mathrm{~J} / \mathrm{kg}^{\circ} \mathrm{C}$ at $70^{\circ} \mathrm{C}$

Collector weight: $110.0 \mathrm{~kg}$

Collector Weight/Area: $28.9 \mathrm{~kg} / \mathrm{m}^{2}$

Collector Fluid Capacity: 8.8 1iters

Collector Fluid Capacity/Area: $2.31 \mathrm{iters} / \mathrm{m}^{2}$

Normal Operating Temperature Range: Intermediate temperatures

Manufacturers Recommended Fluid Flow Rate: 0.4 to 19 liters/min

Manufacturers Recommended Maximum Operating Pressure: $1043 \mathrm{kPa}$ (150 psig) test€ to $1103 \mathrm{kPa}$ ( $160 \mathrm{psig}$ )

Cover Plate Wind Load Maximum: 1819 Pascals (38.0 psf)

*Information provided by manufacturer; not verified by FSEC. 


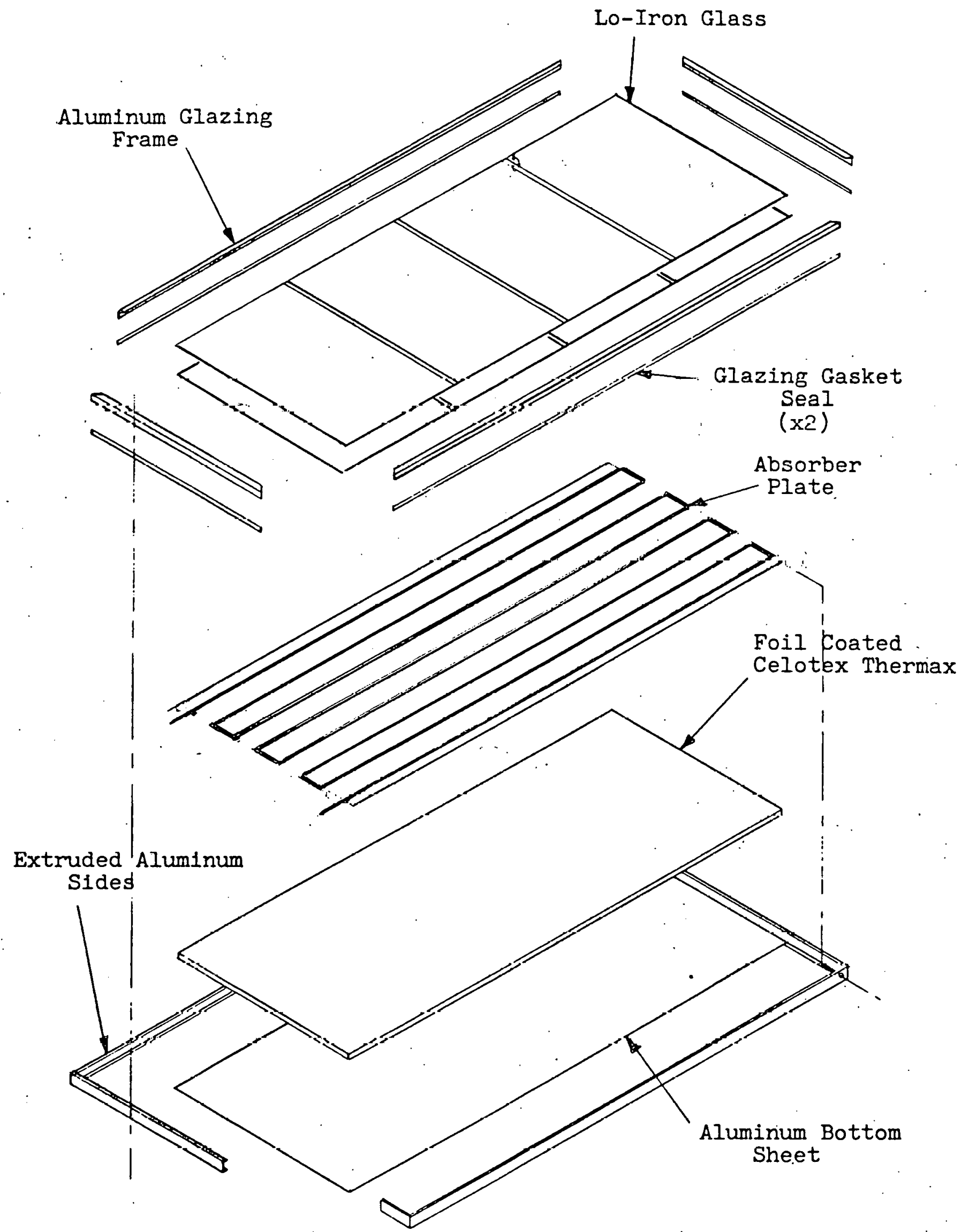

Exploded View SEMCO FP 40 Collector 


\subsection{RESULTS}

\subsection{Introduction}

Results of the thermal performance tests are presented in graphical and tabular form. The first graph shows the efficiency plot in the International System of Units (Metric units). Following this is a comparison of the collector efficiency before and after exposure testing. The third graph presents the results of the incident angle modifier test. Finally, the tabulated data is presented. The performance graphs and the tabulated data are also presented in Section 2.6 in English units of measure.

\subsection{Explanation of Results}

The SEMCO Corporation model FP 40-70 solar collector was tested for time constant, incident angle modifier and thermal performance. The time constant was found to be 2.1 minutes at a flow rate of 4.2 liters per minute ( $1.1 \mathrm{GPM}$ ). The incident angle modifier test, conducted on 11 \& 12 November 1978, is presented in graphical form. A thermal performance test was conducted during the period 11 June to 4 July 1978.

After the performance test was completed the collector was filled with water, capped with a pressure relief valve set at $414 \mathrm{kPa}$ and placed on an exposure rack for a period of 34 days. During this period there were at least thirty days on which the total daily insolation was greater than 4730 watt-hours per square meter ( $1500 \mathrm{Btu} / \mathrm{ft}^{2}$ ) and at least one day on which there was a four-hour period with a minimum insolation level of 946 watts per square meter (300 Btu/ $\mathrm{hr}-\mathrm{ft}^{2}$ ). During the exposure test the collector rack was adjusted to keep the angle between the incoming solar radiation and a normal to the collector surface less than five degrees at solar noon. On three of the last ten days of exposure, the collector was sprayed with water to simulate rain.

A second thermal performance test was conducted during the period 13 to 14 November 1978. The performance equalions in SI unils are as follows:

$\begin{array}{ll}\text { INITIAL TEST } & n=66.1-536.8 \mathrm{DT} / \mathrm{I} \\ \text { RETEST } & n=64.2-360.4 \mathrm{DT} / \mathrm{I}-2429.1(\mathrm{DT} / \mathrm{I})^{2} \\ & n=63.9-520.7 \mathrm{DT} / \mathrm{I} \\ & n=62.6-350.3 \mathrm{DT} / \mathrm{I}-2610.0(\mathrm{DT} / \mathrm{I})^{2}\end{array}$

After all the tests had been completed, the collector was thoroughly in spected. The inspection revealed no observable evidence of deterioration resulting from the exposure test. 


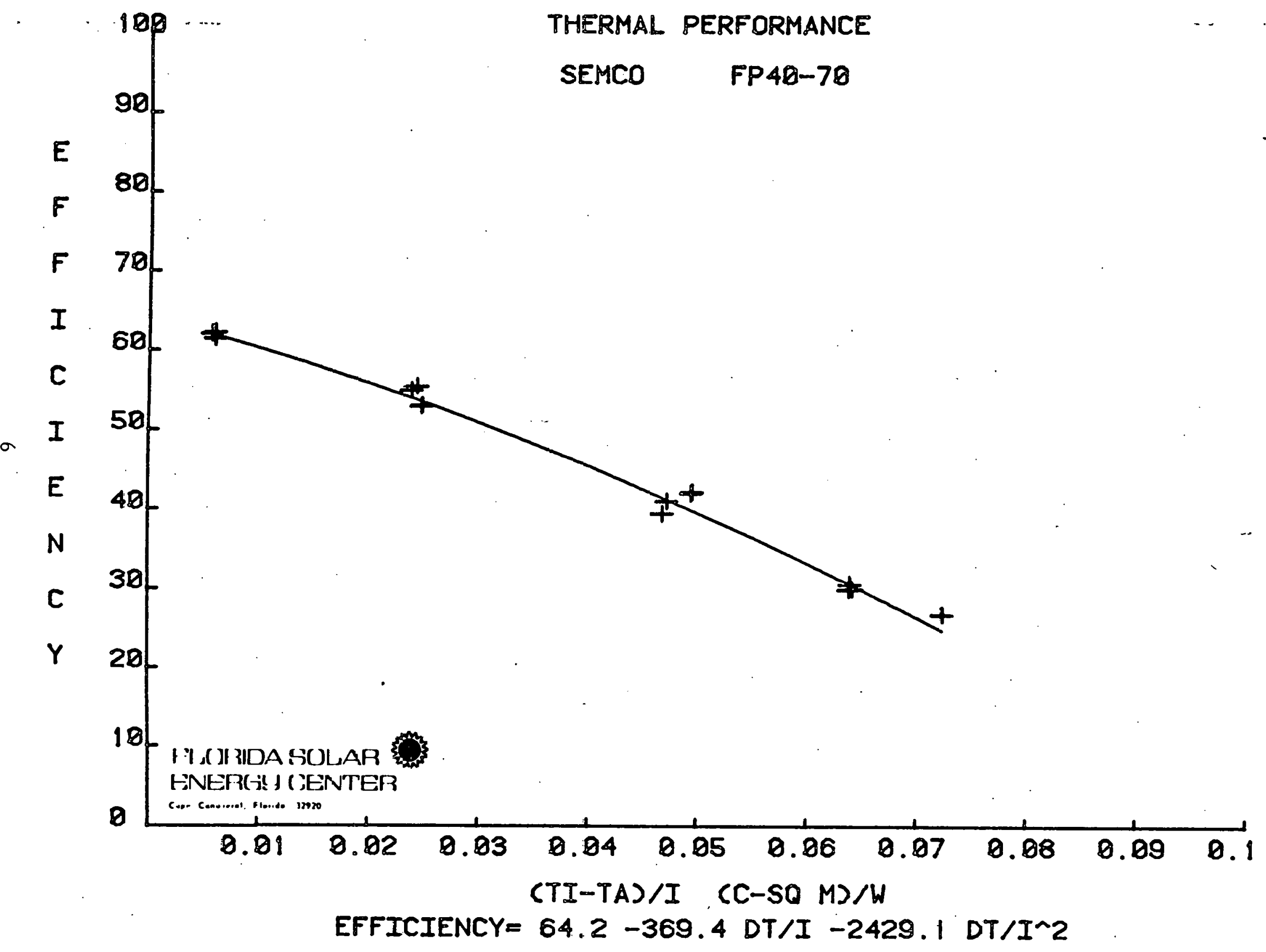




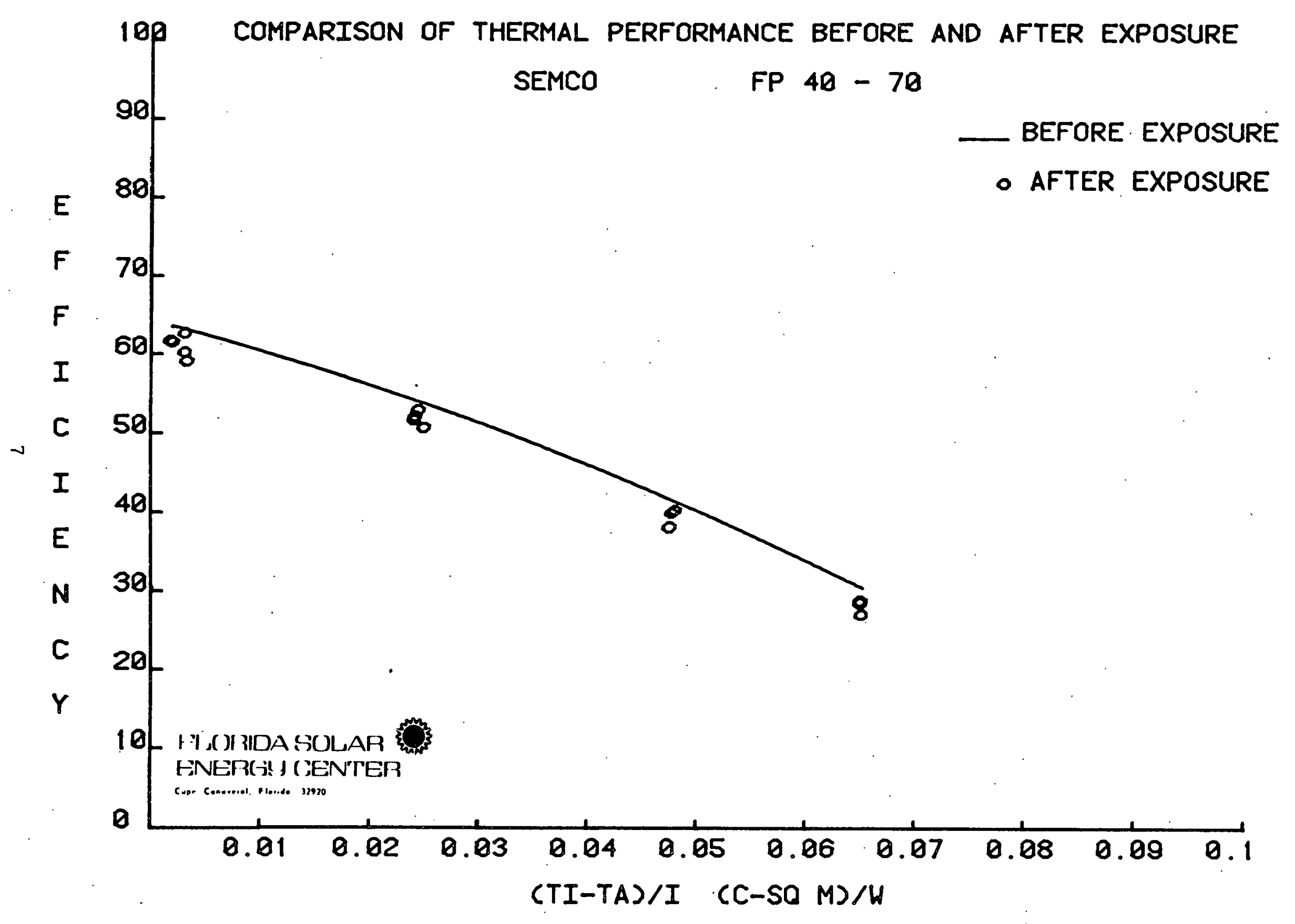




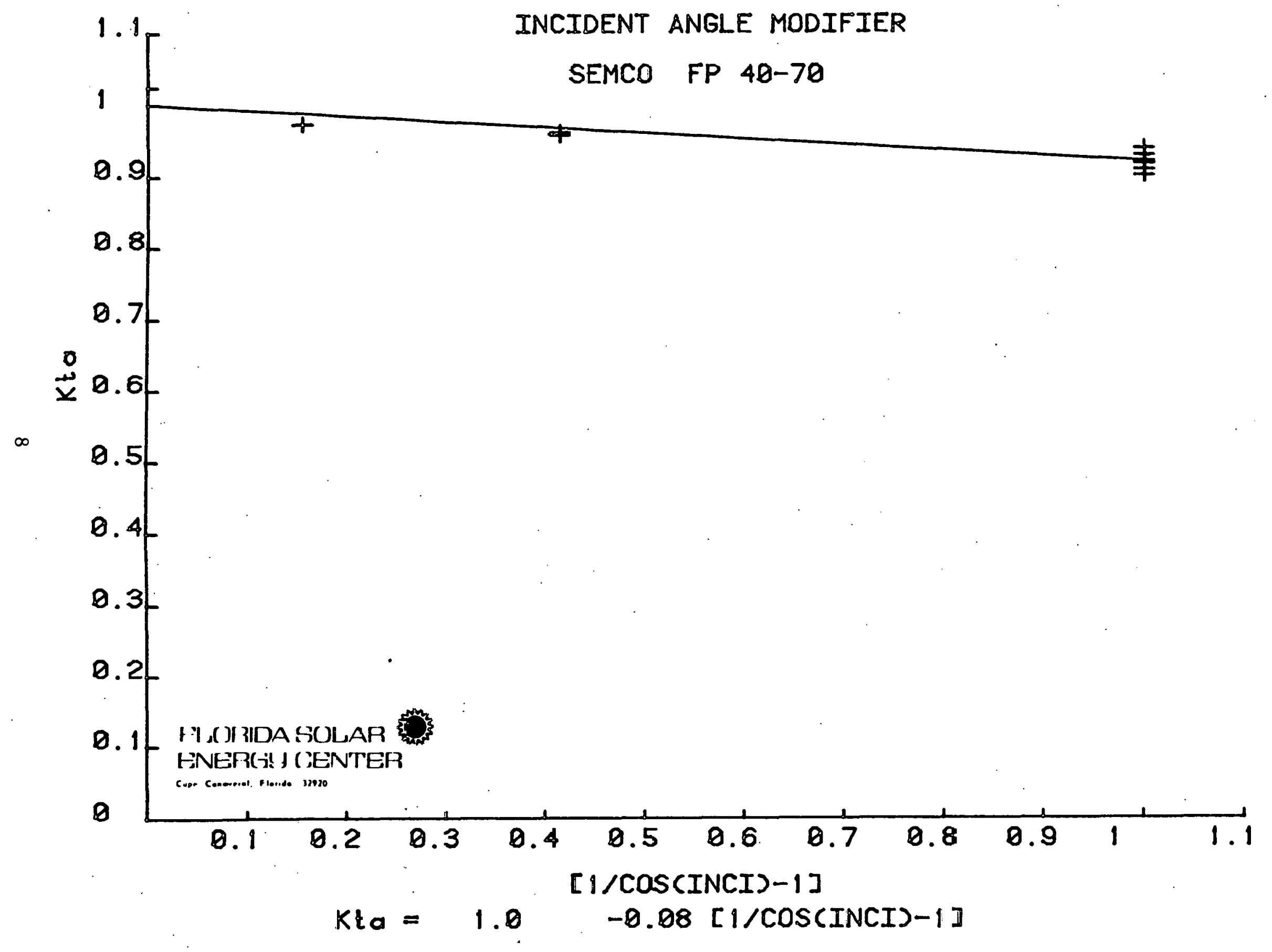




\section{FLOFIIIA SOLAF ENEFGY CENTEF, CAFE CANAUEFAL, FLOFIIIA}

MANUFACTUKER: SEMCO TEST: IIATE :SOLAF TIME: TA : TI : TE : FLOW: AUE IN :TOTAL IN
:STAFT: ENII: (C) : (C) : (C) : L/MIN: W/SQ $M:$ J/SQ $M$

$$
07-J U L-78
$$

$A F E A=3.809 \mathrm{SQ} M$

$:$ IIEL $T: E F F I C:(T I-T A) / I$ :C-MIN: $\%:(C-S Q M) / W$

\begin{tabular}{|c|c|c|c|c|c|c|c|c|c|c|c|}
\hline $6 / 11 / 78$ & $13: 11$ & $13: 16$ & 30.0 & 35.6 & 43.4 & 4.24 & 974.3 & 292277. & 39.4 & 62.1 & 0.0057 \\
\hline $6 / 11 / 78$ & $13: 16$ & $13: 21$ & 29.7 & 35.6 & 43.4 & 4.23 & 974.9 & 292473. & 39.1 & 61.5 & 0.0060 \\
\hline $6 / 11 / 78$ & $13: 21$ & $13: 26$ & 29.6 & 35.5 & 43.5 & 4.23 & 981.0 & 294299. & 39.8 & 62.3 & 0.0060 \\
\hline $6 / 11 / 78$ & $13: 26$ & $13: 31$ & 29.6 & 35.5 & 43.4 & 4.22 & 980.8 & 294240 . & 39.4 & 61.5 & 0.0060 \\
\hline $6 / 11 / 78$ & $14: 16$ & $14: 21$ & 30.7 & 55.3 & 62.6 & 4.26 & 1029.7 & 308921. & 36.9 & 55.0 & 0.0239 \\
\hline $6 / 11 / 78$ & $14: 21$ & $14: 26$ & 30.4 & 55.0 & 62.3 & 4.25 & 1008.5 & 302543 & 36.5 & 55.5 & 0.0244 \\
\hline $6 / 11 / 78$ & $14: 27$ & $14: 32$ & 30.2 & 55.0 & 61.9 & 4.26 & 999.8 & 299949. & 34.5 & 53.0 & 0.0248 \\
\hline $6 / 11 / 78$ & $14: 32$ & $14: 37$ & 30.4 & 55.2 & 62.1 & 4.26 & 996.1 & 298836. & 34.5 & 53.1 & 0.0249 \\
\hline $6 / 11 / 78$ & $15: 10$ & $15: 15$ & 30.1 & 77.6 & 82.8 & 4.33 & 959.2 & 287753 & 26.1 & 42.1 & 0.0495 \\
\hline $6 / 11 / 78$ & $15: 22$ & $15: 27$ & 30.2 & 77.4 & 82.6 & $4 \cdot 34$ & 951.9 & 285563 & 26.0 & 42.3 & 0.0496 \\
\hline $6 / 18 / 78$ & $14: 1$ & $14: 6$ & 28.9 & 95.6 & 99.7 & 4.31 & 1041.8 & 312546. & 20.9 & 30.7 & 0.0640 \\
\hline $6 / 18 / 78$ & $14: 6$ & $14: 11$ & 29.0 & 95.7 & 99.8 & 4.32 & 1042.3 & 312697. & 20.5 & 30.0 & 0.0639 \\
\hline $6 / 18 / 78$ & $14: 11$ & $14: 16$ & 29.0 & 95.8 & 99.9 & 4.32 & 1040.5 & 312137. & 20.5 & 30.1 & 0.0642 \\
\hline $7 / 4 / 78$ & $9: 21$ & $9: 26$ & 31.8 & 96.1 & 99.5 & 4.09 & 889.2 & 266773 & 16.5 & 26.9 & 0.0724 \\
\hline $7 / 4 / 78$ & $10: 51$ & $10: 56$ & 34.0 & 80.7 & 86.0 & 4.18 & 997.1 & 299142. & 26.4 & 39.5 & 0.0469 \\
\hline $7 / 4 / 78$ & $12: 32$ & $12: 37$ & 32.2 & 79.8 & 85.4 & 4.19 & 1006.9 & 302060. & 27.7 & 41.1 & 0.0473 \\
\hline
\end{tabular}

THE FIFST OFIEF EFFICIENCY CUFUE IS: EFFICIENCY $=66.1 \quad-536.8(T I-T A) / I$

THE UNITS ON (TI-TA)/I AFE (C-SQ M)/W.

THE SECONI OFIIEF EFFICIENCY CUFUE IS: EFFICIENCY $=64.2-360.4[1 \mathrm{TT} / \mathrm{I} \quad-2429.1(\mathrm{DT} / \mathrm{I}) 2$ THE UNITS ON IIT/I AFE (C-SR M)/W. IIT=TI-TA 


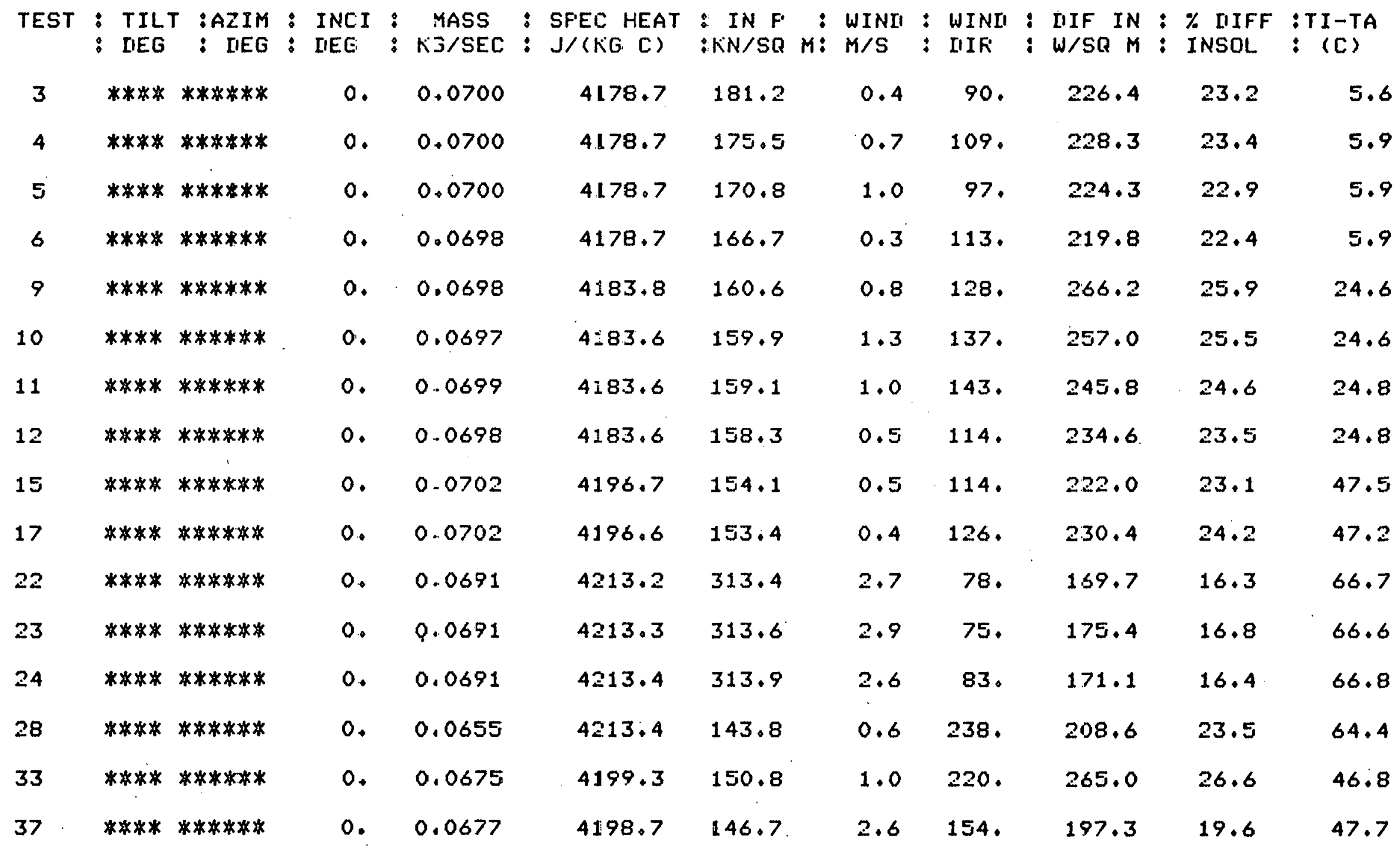




\subsection{Computer Printout Key}

TEST

DATE

SOLAR TIME

TA

TI

TE

FLOW

AVE IN

TOTAL IN

DEL T

EFFIC

$(T I-T A) / I$

TILT

AZIM

INCI

MASS

SPEC HEAT

IN $P$

WIND

WIND DIR

DIF IN

$\%$ DIFF INSOL

TI-TA
Number assigned to the data for a particular test

Date on which the test was performed

Solar time at the start and finish of the test

Ambient air temperature $\left({ }^{0} \mathrm{C}\right.$ or $\left.{ }^{0} \mathrm{~F}\right)$

Temperature of the transfer fluid at the collector inlet $\left({ }^{\circ} \mathrm{C}\right.$ or $\left.\mathrm{OF}\right)$

Temperature of the transfer fluid at the collector exit ${ }^{\circ} \mathrm{C}$ or $\left.{ }^{\circ} \mathrm{F}\right)$

Volumetric flow rate of the transfer fluid (liters/minute or gallons/minute)

Average instantaneous insolation (watts/square meter or Btu/hour-square foot)

Total (integrated) insolation in the plane of the collector during the test period (joules/square meter or Btu/square foot)

Total (integrated) temperature rise across the collector during the test period (degree centigrade minutes or degree fahrenheit minutes)

Calculated collector efficiency for the test period (percent) Value calculated for the abcissa of the efficiency graph $\mathrm{I}=$ average instantaneous insolation. ( ${ }^{\circ} \mathrm{C}$ - square meter/ watt or OF - hour - square foot/Btu).

Angle which the collector was tilted from the horizontal (degrees)

Collector azimuth angle (degrees from due south; east positive)

Angle between the incoming radiation and a normal to the collector surface (degrees)

Mass flow rate of the transfer fluid (kilograms/second or pounds mass/minute).

Specific heat of the transfer fluid (joules/kilogram $-{ }^{\circ} \mathrm{C}$ or $\mathrm{Btu} /$ pound mass - OF)

Gage pressure at the collector inlet (kiloNewtons/square meter or pounds/square inch)

Wind specd (meters/sccond or miles/hour)

Wind direction (degrees east from north)

Diffuse instantaneous insolation (watts/square meter or Btu/ hour-square foot)

Percent of the incoming radiation that was diffuse

Temperature difference between the inlet fluid temperature and ambient air $\left({ }^{\circ} \mathrm{C}\right.$ or $\left.{ }^{\circ} \mathrm{F}\right)$

Note: Stars indicate that no data was taken on the indicated parameter during that test 


\subsection{Results of Static Tests}

2.4.1 Pressure Test

Date of Test: 19 April 1978

Static Test Pressure: 1103 kilopascals (160 psig)

Duration of Test: 15 minutes

2.4.2 Pressure Drop Test

Date of Test: 14 November 1978

Air Temperature: $26.0^{\circ} \mathrm{C} \quad\left(78.8^{\circ} \mathrm{F}\right)$

Inlet Temperature: $26.7^{\circ} \mathrm{C} \quad\left(80.0^{\circ} \mathrm{F}\right)$

Flow Rate: $4.2 \mathrm{~L} / \mathrm{min}$ ( $1.1 \mathrm{GPM}$ )

Inlet Pressure: $137.9 \mathrm{kPa}$ (20.0 psig)

Pressure Drop: $1.11 \mathrm{kPa}$ (0.161 psi)

\subsubsection{Exposure Test}

Start Date: 15 August 1978

Completion Date: 17 September 1978

Ho. of Days of Exposure: 34

No. of Days of Exposure when insolation exceeded 4730 watts $/ \mathrm{m}^{2}\left(1500 \mathrm{BTU} / \mathrm{ft}^{2}\right): \quad 30$

Pressure Relief Setting: $414 \mathrm{kPa}$ (60 psig)

Spray Tests:

$$
\begin{array}{llll}
\text { Dates: } & 6 \text { September } 1978 & 7 \text { September } 1978 & 9 \text { September } 197 \\
\text { Insolation: } & 1040 \text { Watts } / \mathrm{m}^{2} & 1050 \text { Watts } / \mathrm{m}^{2} & 1032 \text { Watts } / \mathrm{m}^{2} \\
& \left(330 \mathrm{Btu} / \mathrm{hr}-\mathrm{ft}^{2}\right) & \left(333 \mathrm{Btu} / \mathrm{hr}-\mathrm{ft}^{2}\right) & \left(327 \mathrm{Btu} / \mathrm{hr}-\mathrm{ft}^{2}\right.
\end{array}
$$

\subsubsection{Inspection Results:}

Cover Platc: No evidence or deteriurdiun Absorber Plate: No evidence of deterioration Absorptive Coating: No evidence of detcrioration Collector Enclosure: No evidence of deterioration Insulation: No evidence of deterioration Gaskets, Caulking \&

Sealants: $\quad$ No evidence of deterioration 


\section{5: Explanation of Efficiency Curve}

The test data is presented in tabular form and as an efficiency curve. The efficiency curve is based on the following equation:

$$
\eta=F_{R}(\tau \alpha)_{e}-F_{R} U_{L} \frac{\left(T_{i}-T_{a}\right)}{I}
$$

where:

$$
\begin{aligned}
\eta & =\text { collector efficiency } \\
F_{R} & =\text { hesat removal factor } \\
(\tau \alpha)_{e} & =\text { effective transmissivity-absorptivity product } \\
U_{L} & =\text { over-all heat loss coefficient } \\
T_{i} & =\text { transfer fluid temperature at the collector inlet } \\
T_{a} & =\text { ambient air temperature } \\
I & =\text { instantaneous level of solar radiation }
\end{aligned}
$$

The standard form of the equation of a straight line is:

$$
Y=b+\dot{m} X
$$

where:

$$
\begin{aligned}
& b=Y \text { axis intercept } \\
& m=\text { slope }
\end{aligned}
$$

From these two equations it can be seen that a straight line should result if a plot of efficiency versus the quantity $\frac{T_{i}-T_{a}}{I}$ is made and if the slope and intercept functions can be assumed constant. It then becomes apparent that the slope of the line is a function of the over-all heat loss coefficient and the $Y$ axis intercept is a function of the transmissivity of the cover plate(s) and the absorptivity of the absorber plate(s). In reality, however, $U_{L}$ is not constant under the test conditions since it varies with the temperature of the collector and ambient weather conditions. Therefore a second order curve is used to describe the thermal performance of the collector. That is:

$$
Y=c+b X+a X^{2}
$$

The intercept is still related to $(\tau \alpha)_{e}$ and the slope at any point on the curve is proportional to the heat loss rate for that value of $\frac{T_{i}-T_{a}}{I}$. 
The efficiency curve does not give absolute values for the overall heat loss coefficient and $(\tau \alpha)_{e}$ since both are multiplied by the factor ${ }^{\alpha} F_{R}$. However, the plot does indicate relative values for these two quantities that can be used for comparing collectors. Determination of the absolute values of $(\tau \alpha)_{e}$ and $U_{L}$ would require additional measurements beyond the tests performed.

The $x$ quantity, $\frac{T_{j}-T_{a}}{I}$, can be determined from measurements made during testing. The collector efficiency can be calculated from the following equation:

$$
\eta=\frac{\dot{m} C_{p} \int \Delta T d t}{A f \dot{I} d t}
$$

where:

$$
\begin{aligned}
\dot{m}= & \text { mass flow rate of the transfer fluid } \\
C_{P}= & \text { specific heat of the transfer fluid } \\
S \Delta T d t= & \text { integrated (total) temperature rise across the collector } \\
A= & \text { gross frontal area } \\
j I d t= & \text { integrated (total) solar radiation received by the collector } \\
& \text { during the test. }
\end{aligned}
$$

The data is collected during a series of test runs. Each data point, represented as a plus sign on the efficiency plot, is the result of a test run, the exact length of the run being determined by the collector time constant. The line drawn on the plot is a second order least squares curve fit of the data points. 


\subsection{Performance Test Results, English Units}

Following is a repetition of the thermal performance curve. Although identical to the previous graphs (see Section 2.1) in content, this graph and computer printout is presented in English units. 


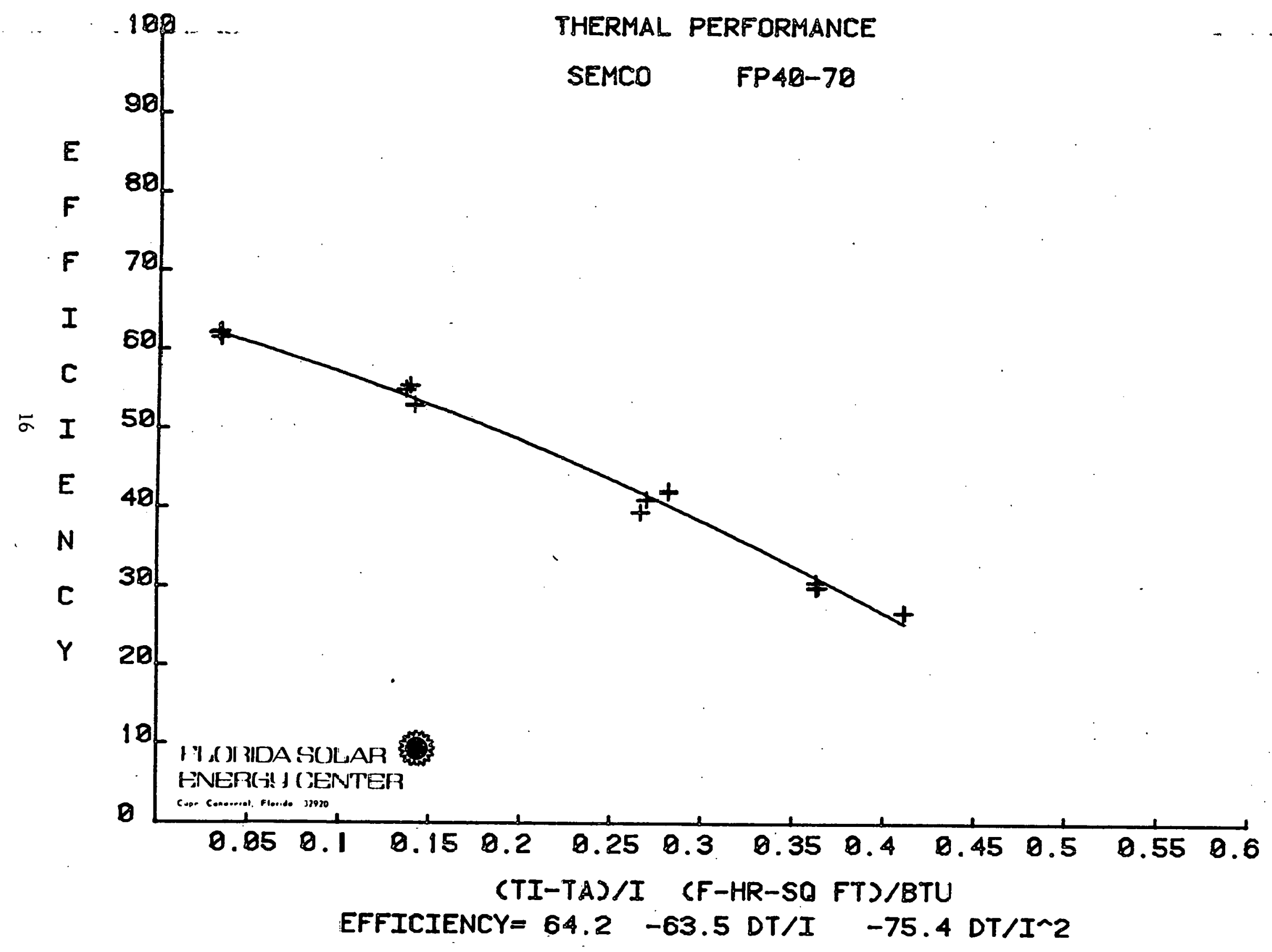




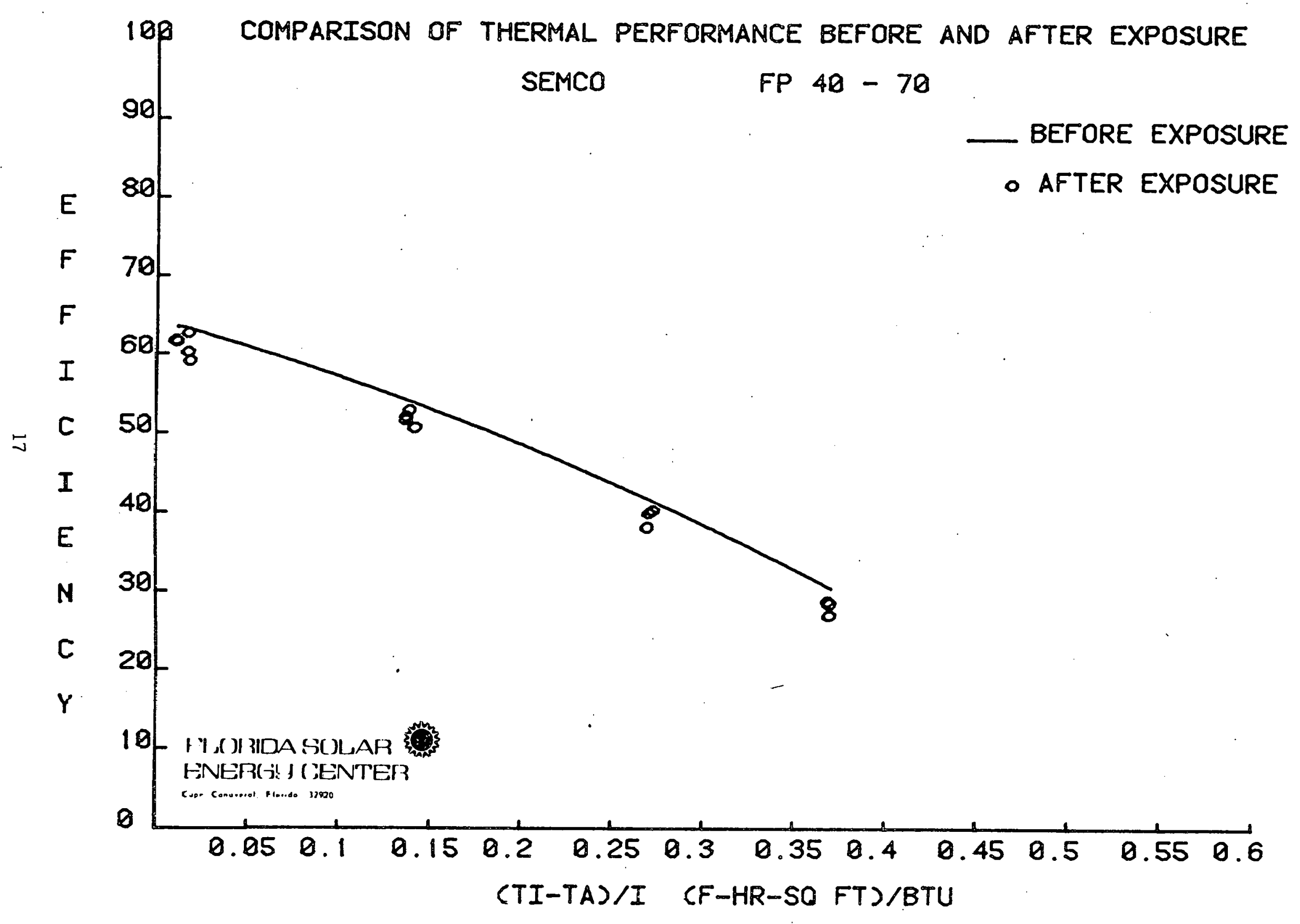




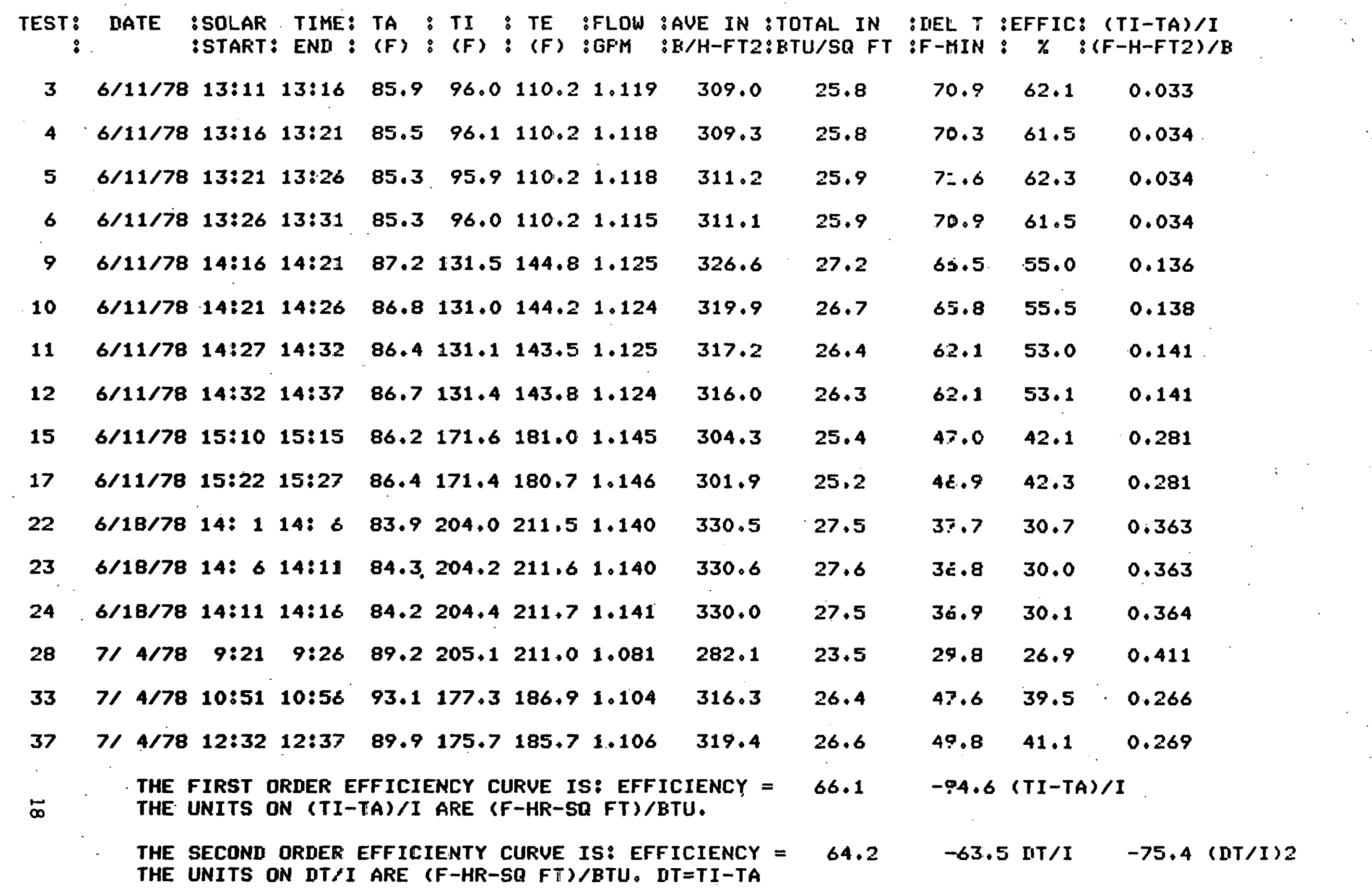


TEST: TILT :AZIM : INCI : MASS : SFEC HEAT: IN F : WINII : WINI : IIIF IN : $\%$ IIIFF :TI-TA : IIEG : IIEG : IIEG :LEM/MIN :BTU/(LEM-F): FSI : MFH : IIIF : E/H-FT2: INSOL : (F)

\begin{tabular}{|c|c|c|c|c|c|c|c|c|c|c|c|}
\hline 3 & $* * * *$ & $* * * *$ & 0.0 & 9.27 & 0.998 & 26.3 & 0.8 & 90. & 71.8 & 23.2 & 10.1 \\
\hline 5 & $* * * *$ & $* * * *$ & 0.0 & 9.26 & 0.998 & 24.8 & 2.3 & 97. & 71.1 & 22.9 & 10.6 \\
\hline 6 & $* * * *$ & $* * * *$ & 0.0 & 9.24 & 0.998 & 24.2 & 0.7 & 113 & 69.7 & 22.4 & 10.6 \\
\hline 9 & $* * * *$ & $* * * *$ & 0.0 & 9.23 & 0.999 & $23 \cdot 3$ & 1.7 & 128 & 84.4 & 25.9 & $44 \cdot 3$ \\
\hline 11 & $* * * *$ & $* * * *$ & 0.0 & 9.24 & 0.999 & 23.1 & 2.2 & 143. & 78.0 & 24.6 & 44.7 \\
\hline 12 & $* * * *$ & $* * * *$ & 0.0 & 9.23 & 0.999 & 23.0 & 1.1 & 114. & 74.4 & 23.5 & 44.7 \\
\hline 15 & $* * * *$ & $* * * *$ & 0.0 & 9.28 & 1.002 & 22.4 & 1.2 & 114. & 70.4 & 23.1 & 85.5 \\
\hline 23 & $* * * *$ & $* * * *$ & 0.0 & .9 .14 & 1.006 & 45.5 & 6.5 & 75. & 55.6 & 16.8 & 120.0 \\
\hline 24 & $* * * *$ & $* * * *$ & 0.0 & 9.14 & 1.006 & 45.5 & 5.8 & 83. & 54.3 & 16.4 & 120.2 \\
\hline 28 & $* * * *$ & $* * * *$ & 0.0 & 8.06 & 1.006 & 20.9 & $1 \cdot 4$ & 238. & 66.2 & 23.5 & 115.8 \\
\hline 33 & $* * * *$ & $* * * *$ & 0.0 & 8.93 & 1.003 & 21.9 & 2.3 & 220 & 84.1 & 26.6 & 84.2 \\
\hline 37 & $* * * *$ & $* * * *$ & 0.0 & 8.96 & 1.003 & 21.3 & 5.8 & 154 & 62.6 & 19.6 & 85.8 \\
\hline
\end{tabular}




\section{APPENDIX A \\ TEST FACILITTIES \\ AND \\ PERFORMANCE TEST PROCEDURES}




\subsection{TEST FACILITY AND PROCEDURES}

The test equipment and configuration used at the Florida Solar Energy Center were chosen to meet the American Society of Heating Refrigerating and AirConditioning Engineers (ASHRAE) requirements described in ASHRAE Standard 93-77. This document sets standards of accuracy on the measuring equipment used and details the procedures that should be followed to measure instantaneous collector efficiency accurately and repeatably.

A brief description of the test facility is included here to help explain the test procedure for determining collector time constant, efficiency, and incident angle modifier.

\subsection{Test Facility}

Test facilities are situated on the property used for the laboratories and offices of FSEC at 300 State Road 401, Cape Canaveral, Florida. The site is north of Port Canaveral at the south entrance to Cape Canaveral AFS. Geodetic position is $28^{\circ} 25^{\prime} \mathrm{N}$. Latitude and $80^{\circ} 36^{\prime}$ $W$. Longitude. The height above sea level is 2.7 meters.

The area available to the Florida Solar Energy Center has allowed the test station to be situated far enough from any structures, objects, trees or parked vehicles that no shadows or reflections are cast onto the collectors during a test. The test site is in an open, grassy area not subject to unusual wind conditions.

The facility has six test stands capable of testing collectors up to 4 feet by 10 feet in size. The stands are designed to track the sun continuously between tilt angles of $0^{\circ}$ (horizontal) and $65^{\circ}$, and azimuth angles of $+100^{\circ}$ from due south for testing normal to the sun. The stands can $\bar{a}$ lso be set in any fixed position for testing.

Adequate warning will be received of the approach of severe weather, thereby allowing time to remove any collector being tested from the test facility and to secure the facility. However, in the event of sudden extreme weather, tie-downs are incorporated to adequately secure the collector and facility.

The FSEC test equipment is shown schematically in Figure 1, which depicts only one of the test stands. The other test stands are similarly equipped and are connected two to six in parallel. The system is operated only with water as the heat transfer fluid.

\subsection{Test Procedure}

The following description of the test methods relates only to testing liquid-filled collectors, and it summarizes the test methods, but does not include any of the specifications on equipment and measurement accuracies spelled out by the ASHRAE Standard.

\subsubsection{Collector Time Constant Determination}

There are two different approved ways to determine the collector time constant, both of which will provide the same result. 
Method 1: With the inlet temperature constant within $+1^{\circ} \mathrm{C}$ of ambient temperature, water is circulated through the collector at the test flow rate until a steady outlet temperature is reached. Then the collector is shaded abruptly, and the time is measured for the temperature difference across the collector to drop to 36.8 percent of its initial steady-state value.

Method 2: With no incoming radiation on the collector, water at $30^{\circ} \mathrm{C}$ above ambient temperature is circulated through the collector at the test flow rate until a steady outlet temperature is reached. Then the inlet temperature is reduced abruptly to the ambient temperature, and the time is measured for the outlet fluid temperature to drop to $11^{\circ} \mathrm{C}$ above ambient ( 36.8 percent of the original difference).

\subsubsection{Thermal Efficiency}

The thermal performance of the collector is determined by obtaining values of instantaneous efficiency for a combination of values of incident insolation, ambient temperature, and inlet fluid temperature. This requires experimentally measuring the rate of incident solar radiation onto the solar collector as well as the rate at which energy is added to the heat transfer fluid as it passes through the collector, all under quasi-steady conditions.

Solar collector efficiency is defined as:

$$
n=\frac{\text { useful energy removed from the collector }}{\text { solar energy incident on the collector }}
$$

and the useful energy can be measured by determining the heat gain in the fluid circulated through the collector. Then,

$$
n=\frac{m C_{p} \Delta t}{I A_{g}}
$$

where:

$\dot{\mathrm{m}}$ is the fluid flow rate, $\mathrm{kg} / \mathrm{s}$,

$C_{p}$ is the specific heat of the fluid (for water it is 4180 to $4200 \mathrm{~J} / \mathrm{kg} \mathrm{C}$,

$\Delta t$ is the difference hetween inlet and outlet fluid temperature, ${ }_{C}$,

I is the incident solar radiation measured in the aperture plane of the collector, $W / m^{2}$, and

$A_{g}$ is the gross area of the collector, $\mathrm{m}^{2}$.

Procedures recommended by ASHRAE require the measurement of average values of I and $\Delta t$ during several separate intervals of testing. Instantaneous values of $I$ and $\Delta t$ should be steady during each test period. A flow rate of about $0.02 \mathrm{~kg} / \mathrm{s} \cdot \mathrm{m}^{2}$ should be maintained, and this flow rate should be steady within \pm 1 percent during each test. At least four tests are run at each of four or more fluid inlet temperatures for a total of at least 16 separate tests. The duration of each test is the collector time constant or five minutes, whichever is larger. 


\subsubsection{Incident Angle Modifier Determination}

Four separate efficiency values are determined in general accordance with the method described in Section 1.2.2. For each "data" point, the inlet temperature of the transfer fluid is controlled to within $+1^{\circ} \mathrm{C}\left(+1.8^{\circ} \mathrm{F}\right)$ of the ambient air temperature. The collector is oriented so that the average incident angles between it and the solar radiation for the four test conditions are respectively approximately 0,30 , 45 and 60 degrees. The foregoing values are appropriate for conventional flat-plate collectors. At least one angle should be greater than the acceptance angle for concentrating collectors. 


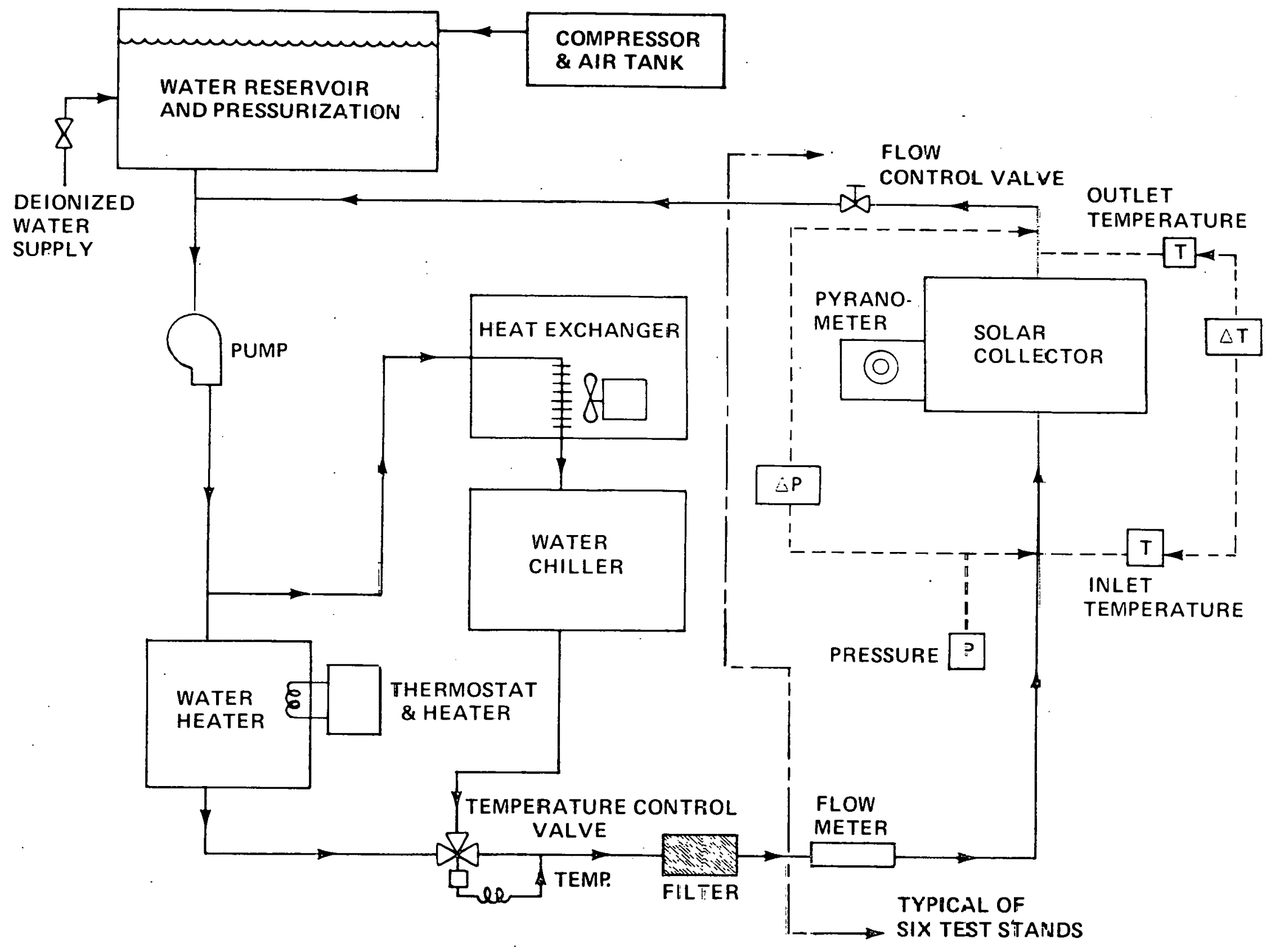


APPENDIX B

TEST METHODS, PERFORMANCE RATINGS

AND STANDARDS

Appendix B is extracted from the Florida Solar

Energy Center document FSEC 77-5 Test Methods

and Minimum Standards for Solar Collectors, dated

June 1977. 
Compliance with minimum standards of durability, safety and general quality of construction will be determined before and after a test sequence that includes:

a. Receiving inspection.

b. Static pressure test.

c. Pre-conditioning exposure test.

d. Collector time constant determination test.

e. Thermal performance test.

f. Incident angle modifier determination test.

g. Thirty-day exposure test.

h. Thermal performance recheck.

i. Final inspection.

\subsection{Receiving Inspection}

\subsubsection{Compliance of Documentation}

Upon receiving a collector for tests, the test engineer will inspect it for compliance to drawings and specifications.

The engineer also will verify receipt of required engineering certifications.

Testing for certification will not be conducted without complete documentation and required engineering certifications.

1.1.2 Compliance to Minimum Quality Standards

The test engineer will verify compliance of the collector to Collector Standards, Section 3.0 .

\subsection{Static Pressure Test}

A static pressure test shall be conducted prior to performance testing as follows:

\subsubsection{Definitions and Scope}

\subsubsection{Types of Collectors}

a. Street pressure solar collectors -- Collectors which, by virtue of their installation in a muniripal water system, will be directly subjected to variations in street water pressure and hot water tank pressure.

b. Low pressure domestic hot water (DHW) and swimming pool solar collectors -- Collectors which, by virture of their installation, will not have a direct fluid interchange with an auxiliary heater or street water pressure. Heat transfer from such collectors to the domestic water system would be accomplished by use of an appropriate heat exchanger. 
c. Hybrid and alternate fluid solar collectors -- Collectors which, by virtue of design, are not intended to have a direct fluid connection to a DHW system. Such units may or may not be designed to accept street pressure.

\subsubsection{Basis of Test Pressure}

a. The test pressure will be $1.2 \times 10^{6}$ Pascals (160 psig) for street pressure collectors, based on:

1. Two times the allowable street gauge pressure $6.5 \mathrm{x}$ 105 Pascals (80 psig) in a dwelling (SBCC, Standard Plumbing Code, Section 1213.9).

2. The test pressure exceeding the required P-T valve relief setting on approved hot water tanks which is $1.14 \times 10^{6}$ Pascals (150 psig).

b. Collectors specified for positive operating pressure less than street pressure $6.5 \times 10^{6}$ Pascals will be pressure-tested at two times the manufacturer's rated operating gauge pressure, but a minimum of $2.7 \times 10^{5}$ Pascals (25 psig).

c. Collectors specified for operating pressure greater than $6.5 \times 10^{5}$ Pascals ( $80 \mathrm{psig}$ ) will be pressure-tested at 1.5 times manufacturer's rated operating gauge pressure or $1.2 \times 10^{6}$ Pascals (160 psig), whichever is greater.

d. Collectors specified for operation at atmosphere pressure or below will be pressure-tested at the discretion of FSEC Test director, but at no greater than $2.7 \times 10^{5}$ Pascals (25 psig).

e. Determination of test pressure will be based on documentation supplied with collector and markings referenced in Section 3.2.1.

\subsubsection{Method of Testing}

a. A pressure gauge will be attached to read the pressure at the exit port of the collector, the collector completely filled with unheated water, and the exit port closed off.

b. Hydraulic pressure will be applied via the inlet port until the gauge indicates the test pressure.

c. After gauge readings have stabilized, pressure will be maintained for 15 minutes.

d. Unit. tested will be considered passable if:

1. A loss of pressure in the system does not occur. 
2. There is no evidence of fluid leakage.

3. There is no evidence of fluid path deterioration (swelling, stretching, etc.).

\subsubsection{Results of Test}

Units that do not pass the static pressure test will not procieed through FSEC testing and will be denied FSEC certification.

\subsection{Collector Pre-Test Conditioning}

Collectors which have met the requirements of Sections 1.1 and 1.2 shall be subject to pre-conditioning exposure to the environment.

\subsubsection{Purpose}

The purposc of this test is lu expose the collector to radiation and weather conditions for a short period of time to age the unit in order that subsequent performance testing will be more representative of its performance during actual operation.

\subsubsection{Scope}

This standard test method can be applied to any solar collector that meets the requirements for thermal performance testing, ASHRAE 93-77.

\subsubsection{Method of Testing}

The unfilled collector shall be mounted securely to an exposure rack and exposed to direct sunlight and weather for a minimum of three cumulative days during which the mean incident solar radiation measured in the plane of the collector shall be $17000 \mathrm{~kJ} / \mathrm{m}^{2}$.day (1500 Btu/ft? day). The angle of exposure shail be such that the angle of solar incidence at solar noon is within $10^{\circ}$ of the normal to the plane of the aperture.

\subsection{Collector Time Constant}

A time constant test will be conducted to determine the time required for the outlet fluid temperature to attain 63.2 percent. nf its steady state value following a step change in the input. This figure is used during the thermal performance test as the time period over which temperature and insolation data are integrated to obtain the computed efficiency values.

\subsubsection{Procedures Adopted}

The test method used will conform to the method described in lie Allerican Society of Heating, Refrigerating and Air-Conditioning Engineers (ASHRAE) Standard 93-77, "Methods of Testing to Determine the Thermal Performance of Solar Collectors." 


\subsection{Thermal Performance}

A thermal performance test will be conducted on those collectors that have passed the requirements of Sections $1.1,1.2$ and 1.3 and for which the collector time constant has been determined.

\subsubsection{Procedures Adopted.}

The test method used will conform to the method described in ASHRAE Standard 93-77 "Methods of Testing to Determine the Thermal Performance of Solar Collectors" as modified by FSEC. The following modification to the ASHRAE method is allowed:

Only collectors using a liquid heat transfer medium will be tested at FSEC by this method.

\subsubsection{Results}

A test report will be prepared containing the "Data and Information to be Reported" (Table 2) specified in ASHRAE Standards 93-77. The principal result is a curve of collector thermal efficiency.

\subsection{Collector Incident Angle Modifier Determination}

The thermal performance curve for a collector is determined (Section 1.5) when the insolation incident on the collector is within 30 degrees of normal to the aperture of the collector. To predict collector performance over a wide range of conditions, a test will be conducted to determine the collector incident angle modifier. This is used to modify the efficiency curve (determined within 30 degrees of normal incidence) to account for changes in performance as a function of the sun's incident angle.

\subsubsection{Procedure Adopted}

The test method used will conform to the method described in ASHRAE Standard 93-77, "Methods of Testing to Determine the Thermal Performance of Solar Collectors."

\subsection{Exposure Test}

\subsubsection{Purpose}

The purpose of this test is to verify collector thermal performance and integrity of construction after at least 30 days of exposure to adverse conditions.*

\footnotetext{
*There presently exist no correlations between real time and accelerated aging; such correlations need to be established to properly quantify the results obtained from this short-term test
} 


\subsubsection{Scope}

This standard test method can be applied to any solar collectors that meet the requirements for Thermal Performance Testing, ASHRAE Standard 93-77.

\subsubsection{Pre-Exposure Preparation}

1. Liquid collectors intended for use in all systems (with or without draindown) shall be filled completely with clean tap water, following which the inlet shall be sealed and the outlet provided with a pressure relief valve set to a value within $10 \%$ of the manufacturer's recommended maximum operating pressure.

2. Liquid collectors limited to use in systems that draindown when not operating shall be filled completely with cleall tap water, tollowing which the water shall be allowed to gravity-drain for 15 minutes with the collector mounted at a $45^{\circ}$ tilt angle. The collector inlet then shall be sealed and the outlet provided with a pressure relief valve set to a value within $10 \%$ of the manufacturer's recommended operating pressure.

\subsubsection{Exposure Conditions}

Exposure conditions shall consist of 30 'days of cumulative exposure to a minimum daily incident solar radiation flux of $1500 \mathrm{Btu} / \mathrm{ft}^{2}$. day as measured in the plane of the collector aperture. The exposure conditions shall include at least one consecutive four-hour period with a minimum flux of 300 $\mathrm{Btu} / \mathrm{ft}^{2} \cdot \mathrm{hr}$. In water-filled specimens, this must occur after water boilout has occurred. The collector shall be mounted to a rack at a tilt angle such that the incident solar radiaLiun during solar noon is within \pm 100 of the normal to the plane of the aperture.

\subsubsection{Spray Test}

The collector structure and performance should not be degraded by either thermal shock or moisture penetration caused by heavy rains falling on the heated collector.

During a five-minute period on three different days of the exposure test, the collector shall be subjected to heavy spray from above or in front of the collector. Spray testing shall be conducted after at least one hour of direct sun (minimum $\left.950 \mathrm{~W} / \mathrm{m}^{2}\left(300 \mathrm{Btu} / \mathrm{ft}^{2} \cdot \mathrm{hr}\right)\right)$ and within two hours of solar noon. These three spray tests shall be conducted during the last 10 days of the exposure test.

Water delivery shall. be at a rate not less than 0.1 liter/min per square meter of collector $\left(0.0025 \mathrm{gal} / \mathrm{min} \cdot \mathrm{ft}^{2}\right)$ with the spray pattern designed to wet the surface that would be wet during a normal rain shower. 


\subsubsection{Results}

No component of the collector shall be replaced or repaired once the exposure test sequence has begun.

\subsubsection{Test Termination}

The test will be terminated if it is apparent, without collector disassembly, that the unit being tested no longer meets the quality requirements of Section 1.9 below. Complete diagnostic testing of failed collectors will be conducted as described in Section 1:9.

\subsubsection{Data Recorded}

a. Insolation level, ambient temperature, wind speed, and humidity on an hourly basis during all exposure testing.

b. A regularly scheduled weekly visual inspection shall be made, and a record of changes in the physical construction appearance of the collector shall be kept.

c. If a failure occurs as described by Section 1.7.6.1, time and reason for failure shall be recorded and the test terminated.

\subsection{Thermal Performance Recheck}

After completion of the exposure test, the collector thermal performance shall be rechecked to provide a quantitative determination of the extent of any degradation. The thermal performance test procedure outlined in Section 1.5 will be used.

\subsubsection{Results}

The efficiency curve calculated from the results of the performance recheck shall be compared with the pre-exposure-test efficiency curve.

\subsubsection{Failure}

The vertical-axis intercept and the slope of the pre-exposure and post-exposure first-order efficiency curves shall be compared.*

a. If the performance recheck intercept is less than 90 percent of the pre-test intercept, degradation is excessive and the collector will not be certified by FSEC, or

\footnotetext{
*Concentrating collectors will be tested only to operating temperatures of about $175^{\circ} \mathrm{C}\left(350^{\circ} \mathrm{F}\right)$, and for this criterion the first-order curve for operation up to $175^{\circ} \mathrm{C}$ will be used.
} 
b. If the absolute value of the post-test slope is more than 110 percent of the absolute value of the pre-test slope, degradation is excessive, and the collector will not be certified by FSEC.

\subsection{Quality Check}

\subsubsection{Purpose}

After exposure testing, a visual inspection of the collector should not show any impairment of function or evidence of degradation which could be expected in normal service to progress to the point of causing failure or significant impairment of function.

\subsubsection{Bases for Quality Determination}

Collector pertormance and structural integrity should not be degraded as a result of the exposure test. Whereas the principal means of determining degradation will be the Thermal Performance Recheck, Section 1.8, a visual inspection will be performed on all collectors that have been subjected to the exposure test to identify causes of performance failure or conditions that may lead to abnormally short collector life.

Evidence of the deterioration described below will be cause for denying FSEC certification.

\subsubsection{Cover Plates and Absorber Covers}

After exposure testing, there shall be no clouding, cracking, crazing, warping or buckling of cover plate and absorber cover materials.

\subsubsection{Absorber}

After exposure testing, none of the following defects shall be apparent:

a. Severe deformation* of the absorber

b. Severe deformation* of the fluid flow passages

c. Loss of bonding between fluid flow passages and absorber plate.

d. Leakage from fluid flow passages or connections

e. Loss of mounting integrity

f. Evidence of severe rorrosinn* or nther detcerioration caused by chemical action (corrosive fluxes, volatiles from collector materials, salt spray, etc.).

\subsubsection{Absorptive Coatings}

After exposure testing, there shall be no evidence of checking, cracking, blistering or flaking of the absorber coating.

\footnotetext{
*Deformation or corrosion shall be considered severe if it impairs the function of the ccillector or there is evidence that it will progress under operating conditions and lead to impairment of function.
} 


\subsubsection{Collector Enclosure}

After exposure testing, there shall be no cracking or warping of the collector enclosure materials.

\subsubsection{Reflective Surfaces}

After exposure testing, there shall be no cracking, crazing or delamination of reflective surfaces:

\subsubsection{Insulation}

a. After exposure tests, there shall be no swelling or other detrimental changes in the collector insulation which adversely affect collector performance.

b. There shall be no evidence that water is being retained in the insulation.

1.9.2.7 Gaskets, Caulking and Sealants

Gaskets and sealants shall not exhibit cracking, loss of elasticity or loss of adhesion

1.9.2.8 Hoses

After exposure tests, there shall be no evidence of leakage or damage to hoses used inside the collector enclosure or leakage from mechanical connections.

\subsection{STANDARD METHOD FOR THERMAL PERFORMANCE RATING}

\subsection{Purpose}

To provide a uniform basis for comparing solar collectors sold in Florida by applying results of the thermal performance test to a set of representative operating conditions, a thermal performance rating will be assigned to collecturs certified by FSEC.

\subsection{Scope}

This method is suitable only for rating collectors that utilize both direct and diffuse components of incident solar radiation and do not track or move during operation.

The thermal performance rating will be composed of three numbers, each one the calculated total daily thermal output of the collector at a different fixed average fluid temperature, under insolation and ambient temperature conditions defined as "Standard Day" below. The rating is intended to be representative of performance under operating conditions encountered in Florida. Collectors may show different daily thermal outputs for environmental conditions other than those used for this standard rating method. 


\subsection{Conditions}

\subsubsection{Operating Temperature}

A single set of environmental conditions will be used to provide an estimate of collector thermal output for the following three average fluid temperatures:
a. Low temperature $(\mathrm{LT}) ; 35^{\circ} \mathrm{C}\left(95^{\circ} \mathrm{F}\right)$; representative of opera- ting conditions for swimming pool heaters
b. Intermediate temperature (IT); $50^{\circ} \mathrm{C}\left(122^{\circ} \mathrm{F}\right)$; representative of operating conditions for domestic water heating. operating conditions for (suitably designed) absorption chillers.
c. High temperature $(\mathrm{HT})^{\star} ; 100^{\circ} \mathrm{C}\left(212^{\circ} \mathrm{F}\right)$; representative of

\subsubsection{Standard Day}

The following temperature and insolation conditions are used to represent one 10-hour period of collector operation called the "Standard Day."
a. Anbient temperature will average $27^{\circ} \mathrm{C}\left(81^{\circ} \mathrm{F}\right)$ as distributed in Table 2.1.
b. A different insolation will be assumed for each of 10 hours as shown in Table 2.1.

Table 2.1 Insolation and Ambient Temperature for Standard Day

\begin{tabular}{ccc}
$\frac{\text { Watts } / \mathrm{m}^{2}}{50}$ & $\frac{\mathrm{Btu} / \mathrm{ft}^{2} \cdot \mathrm{hr}}{16}$ & $\frac{\text { Temp. }{ }^{\circ} \mathrm{C}}{24}$ \\
151 & 48 & 26 \\
252 & 80 & 25 \\
353 & 112 & 26 \\
454 & 144 & 27 \\
555 & 166 & 27 \\
656 & 208 & 28 \\
757 & 240 & 29 \\
858 & 272 & 29 \\
959 & 304 & 30 \\
\hline & & -1 .
\end{tabular}

\footnotetext{
*If there is no calculated output from a collector under a given operating temperature, the rating for that temperature will be given as "N/A". to signify that the collector is not applicable to operation at this temperature
} 


\subsection{Equations and Definitions}

Measured collector efficiency for normal incidence may be expressed by a second-order equation of the form,

$$
n=a+b x+c x^{2}
$$

where $a, b$ and $c$ are computed constants for a given collector, and

$$
x=\frac{t_{a v g}-t_{a m b}}{I}
$$

in which $t_{a v g}$ is the average collector fluid temperature*,

tamb is the ambient air temperature, and

$I$ is the total insolation measured in the plane of the collector.

\subsection{Calculations}

Collector output for one hour may be estimated by

$$
q=n I
$$

where $n$ is expressed by equation (2-1) above, and $I$ is the total insolation during the hour.

The summation of hourly output gives the output for the Standard Day; that is, for the second-order efficiency curve,

$$
Q_{T}=\sum_{i=1}^{10} \quad I_{i}\left(a-b x_{i}-c x_{i}{ }^{2}\right)
$$

\subsection{COLLECTOR STANDARDS}

The following standards of construction and use of material are required and apply to the collector both prior to and subsequent to testing. A collector not meeting these standards cannot bear the Florida Solar Energy Center label of certification.

\subsection{Cover Plate, Absorber Cover}

All glass cover plates must be either double-strength or tempered.

\subsection{Collector Assembly}

\subsubsection{Identification Plate}

Each collector shall bear a permanent identification plate with the following information:

\footnotetext{
*The efficiency plot in the test report is based on fluid inlet temperatures instead of average temperature. This results in values for $a, b$ and $c$ given with the plotted curve that are different from those used in the calculation of performance rating.
} 
a. Manufacturer's name,

b. Manufacturer's address,

c. Manufacturer's model number,

d. Maximum operating pressure, psig, and

e. Voltage and current requirements of integral controls or motors

3.2.2 Access to Components

Collector components requiring routine maintenance or periodic repair or replacements, shall be readily accessible by use of standard hand tools and without major disassembly of the collector.

\subsubsection{Condensation}

The collector shall be designed to prevent condensatc buildup. The use of desiccants to control condensation will be permitted,

\subsubsection{Openings}

All openings in the collector enclosure shall be protected to prevent the entry of insects and vermin. 